\title{
Bycatch of loggerhead sea turtles: insights from 14 years of stranding data
}

\author{
Jesús Tomás ${ }^{1, *}$, Patricia Gozalbes ${ }^{2}$, Juan Antonio Raga ${ }^{2}$, Brendan J. Godley ${ }^{1}$ \\ ${ }^{1}$ Centre for Ecology and Conservation, University of Exeter, Cornwall Campus, Penryn TR10 9EZ, UK \\ ${ }^{2}$ Cavanilles Institute of Biodiversity and Evolutionary Biology, University of Valencia, Aptdo. 22085, 46071 Valencia, Spain
}

\begin{abstract}
We present a detailed analysis of sea turtle strandings $(\mathrm{n}=619)$ over a $14 \mathrm{yr}$ period (1993 to 2006) from the Valencian Community (eastern Spain). Loggerhead turtles Caretta caretta accounted for $98.1 \%$ of recorded strandings. Although we detected an increasing trend in the annual number of strandings over the study period, we expect that this was driven primarily by the increase in detection effort. Loggerhead turtles were mainly juveniles (mean \pm SD curved carapace length from notch to tip $[\mathrm{CCL}]=53.6 \pm 12.6$; range: 16 to $80.2 \mathrm{~cm}, \mathrm{n}=312$ ) and strandings were far more frequent in summer months (69.6\% June to September). We believe that interaction with longline fisheries was by far the main cause of observed stranding ( $>28 \%$ of all cases, $43.5 \%$ of 393 turtles with likely mortality cause identified). Turtles showing signs of interaction with longlines were, on average, larger (CCL $=57.5 \pm 10.4$; range: 29.8 to $80.2 \mathrm{~cm}, \mathrm{n}=116$ ) than turtles stranded due to other causes $(\mathrm{CCL}=51.4 \pm 13.3$; range: 16 to $79 \mathrm{~cm}, \mathrm{n}=196$; $t$-test: $t=-4.49, \mathrm{p}<0.001$ ) and were more frequent in summer months, when longline fishing effort off the coast was highest. Recent reductions in longline effort may have led to a decrease in recent years in the proportion of stranded turtles with evidence of longline interaction. Although inferences from stranding data must be subject to a number of caveats, when considered over wide spatio-temporal extents and in conjunction with other data sources, they can offer useful insights into the geographic ranges, seasonal distribution and life history of marine species of conservation concern.
\end{abstract}

KEY WORDS: Loggerhead sea turtle $\cdot$ Caretta caretta $\cdot$ Fisheries bycatch $\cdot$ Strandings $\cdot$ Spanish Mediterranean · Conservation

\section{INTRODUCTION}

Many species of large marine vertebrates, such as marine mammals, sea turtles or seabirds are subject to bycatch in commercial fisheries operations, and these captures may occur in substantial numbers (Lewison et al. 2004a). Assessment of the impact of bycatch, however, is difficult (Hall et al. 2000, Lewison et al. 2004b). Worldwide, sea turtles are caught primarily by trawl, pelagic longline and coastal gillnet fisheries (Hays et al. 2003, Lewison \& Crowder 2007, Peckham et al. 2007). In the Mediterranean Sea, thousands of turtles are estimated to be incidentally captured or entangled by longline fisheries each year (Kemf et al. 2000, Lewison et al. 2004a). Although sea turtle bycatch has been reported from other fisheries throughout the Mediterranean (Godley et al. 1998, Carreras et al. 2004, Casale et al. 2005), bycatch in longline fisheries has been cited as the most important source of anthropogenic mortality for sea turtles (Gerosa \& Casale 1999), particularly in the western basin of this sea (Camiñas \& De la Serna 1995, Laurent et al. 2001, Camiñas et al. 2006).

Two key points generally compromise bycatch studies: (1) data limitations and (2) spatial coverage of bycatch information (Lewison et al. 2004b). With respect to data limitations, direct measurements of bycatch require on-board observation programmes, which are costly and require independent and welltrained observers. Although additional data can be derived from catch books/interviews with fishermen, these often need validation (Carreras et al. 2004). 
Concerning spatial scale, fishing effort is globally distributed and many large marine vertebrates, including sea turtles, have ocean-wide distributions. Therefore, information must often be compiled from smaller scale studies to form large-scale perspectives of the impact of incidental catch on non-target species. Although integrated studies based on observer data and interviews provide some data on the number of turtles caught and post-capture mortality rates (Carreras et al. 2004, Carranza et al. 2006, Mejuto et al. 2006 and references therein), the sample sizes in these studies are typically small (i.e. with low statistical power), and the amount of observed gear is dwarfed by the overall fishing effort of the fishery in question (Lewison et al. 2004b). Most importantly, very few studies are able to provide accurate postcapture mortality rates (Chaloupka et al. 2004, Sasso \& Epperly 2007), as not every interaction with longline gear is lethal.

Additional insight can be gathered from stranding data. We consider strandings as turtles washed ashore dead or alive or found floating dead or alive in coastal waters. Although inferences from these data are subject to a number of caveats, when integrated over wide spatio-temporal extents, stranding data can provide information about geographic ranges, seasonal distribution and life history of marine vertebrates, including sea turtles, particularly for life stages underrepresented in the literature (Witt et al. 2007). For instance, Snover et al. (2007) use data of stranded turtles to ascertain and validate loggerhead turtle growth rates. Furthermore, when integrated with careful postmortem examination, these data can also allow inferences to be made on patterns of bycatch (Panagopoulos et al. 2003).

The location of the Valencian Community (eastern Spain) is of special interest in relation to loggerhead sea turtle Caretta caretta distribution and conservation for the Atlantic and Mediterranean basins. Although adults from Mediterranean nesting stocks appear limited to the eastern basin (Godley et al 2003, Broderick et al. 2007, Zbinden et al. 2008), the western Mediterranean hosts juveniles from both Mediterranean and Atlantic rookeries (Laurent et al. 1998). These 2 stocks appear to remain segregated. Cape La Nao (Fig. 1) is likely the mainland boundary between groups, with the Mediterranean stocks remaining in the northern Balearic Sea and the Atlantic individuals in the Algerian basin, with limited exchange (Cardona et al. 2005, Carreras et al. 2006, Revelles et al. 2007a). Here we present a detailed spatio-temporal analysis of the patterns of marine turtle stranding along the coastline of the Valencian Community from $14 \mathrm{yr}$ of data, to seek insights into patterns of bycatch and other anthropogenic impacts in the region.

\section{MATERIALS AND METHODS}

Sea turtle stranding data were collected between 1993 and 2006 in the Valencian Community by a stranding network involving public and private institutions, including public rescue centres and aquaria in the region. This network records dead or injured turtles stranded on beaches, or turtles found floating dead or in a weakened condition. It is coordinated via a $24 \mathrm{~h}$ telephone hotline.

The Valencian Community is a region with a high degree of development and tourism along its coast and is comprised of the 3 coastal provinces of, from north to south, Castellón, Valencia and Alicante; totalling $419 \mathrm{~km}$ of coastline that extends from $40^{\circ} 31^{\prime} \mathrm{N}, 0^{\circ} 31^{\prime} \mathrm{E}$ to $37^{\circ} 51^{\prime} \mathrm{N}, 0^{\circ} 45^{\prime} \mathrm{W}$ (Tomás et al. 2003a). Cape La Nao is located in the north of Alicante province $\left(38^{\circ} 44^{\prime} \mathrm{N}, 0^{\circ} 14^{\prime} \mathrm{E}\right.$, Fig. 1$)$ and divides the coast studied into 2 stretches of 257 and $162 \mathrm{~km}$, north and south, respectively. Most stranding data were reported to the coordinators of the network with no precise geographical position provided. For this reason, we collated stranding data by municipality, except for those with the longest coastlines, Valencia City in Valencia Province and Elche in Alicante Province; for these municipalities we created 3 and 2 subareas, respectively. Although we recognise that there is some variation in the length of coastline among sections, we feel that this level of data aggregation allows sufficient spatial resolution to elucidate patterns of distribution within the study area.

Animals found alive were moved to public rescue centres and subjected to veterinary examination and rehabilitation; the carcasses found were brought, where possible, to the research installations of the University of Valencia (UV) for necropsy. We measured turtles (curved carapace length notch to tip $[C C L]$ and curved carapace width [CCW]), identified them to species level, and determined the likely cause of death based on a complete external and internal examination. A trained team performed necropsies of fresh carcases following a detailed protocol. If no severe lesions were detected in the presence of evidence of anthropogenic impacts (such as ingested longline gear, marks of nets around flippers or neck), these were assigned as the stranding cause. In cases when there was evidence of multiple lesions, the most severe and recent was assigned as the primary cause of stranding. Interaction with longline fishery was assigned as the stranding cause when branch lines and/or hooks were found upon examination. We were not able to identify the cause of stranding in all the cases, as we did not have access to all animals due to logistical constraints. 


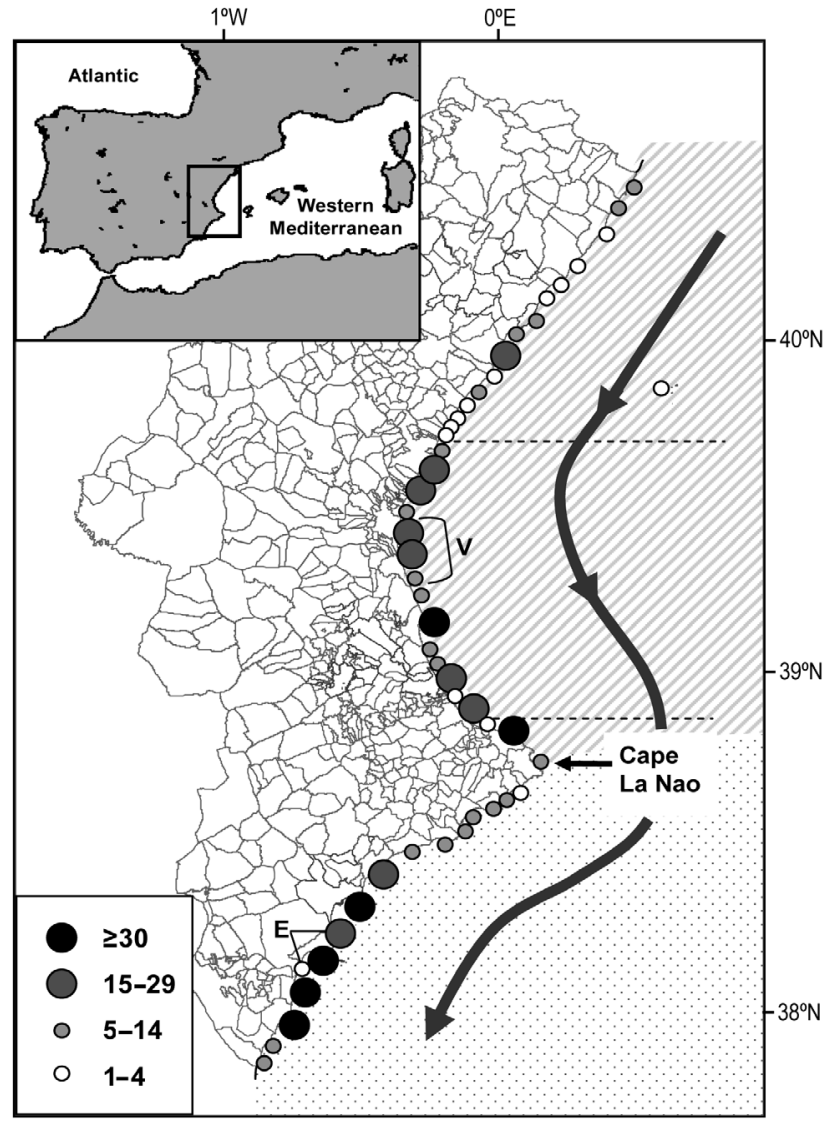

Fig. 1. Caretta caretta. Study area and distribution of strandings per municipality in the Valencian Community for the period 1993-2006. Black dashed lines represent the coastal limits of provinces (north to south: Castellón, Valencia, Alicante). Grey arrow represents main surface current (Millot 1999). Dotted and hatched areas represent the areas occupied mainly by Atlantic and Mediterranean loggerhead turtles, respectively, according to Carreras et al. (2006). V: municipality of Valencia; E: municipality of Elche (see 'Materials and methods'). Strandings at sea correspond to those registered in the Columbretes Archipelago

\section{RESULTS}

\section{Total strandings, species and life stages}

Between 1993 and 2006, we recorded a total of 619 sea turtles stranded $(46.7 \pm 28.2$ annually, mean $\pm \mathrm{SD}$; range: 12 to 124). Strandings were recorded throughout the study area in almost every coastal municipality (Fig. 1). There was no significant difference in the total of stranding records between the regions south (301) and north (318) of Cape La Nao (chi-squared test, $\chi^{2}=$ 0.467 , df $=1, p=0.49$ ). However, overall density of strandings was higher south of the cape (south: 1.9 turtles $\mathrm{km}^{-1}$; north: 1.2 turtles $\mathrm{km}^{-1}$ ). In each of these 2 areas we observed an increasing north-south pattern in stranding occurrence (Fig. 1).
With the exception of 2001, there was an apparent general increase in strandings observed between 1993 and 2006, but since 2000 the annual number of stranded turtles appears to have been relatively stable (Fig. 2a), at a mean density of 0.13 stranded turtles $\mathrm{km}^{-1}$ of coast $\mathrm{yr}^{-1}$.

The vast majority of stranded turtles (98.1\%) recorded were loggerheads. The remaining $1.9 \%$ comprised Kemp's ridleys Lepidochelys kempii $(\mathrm{n}=2)$ (Tomás et al. 2003b, Tomás \& Raga 2007) and leatherbacks Dermochelys coriacea $(n=2)$ (Tomás et al. 2003a), while another 8 carcases were not definitively identified to species. To date, only 1 green turtle Chelonia mydas has been reported from the Valencian Community, and this was prior to the present study (Raga \& Salinas 1990).

Mean CCL for the stranded loggerheads was $53.6 \pm$ $12.6 \mathrm{~cm}$ ( $\mathrm{n}=312$; range: 16 to 80.2 ). The size distribution of these turtles is larger than expected and includes animals of all size classes from neritic juvenile to adult whether from Mediterranean (Broderick et al. 2003) or Atlantic populations (Bolten 2003, Kamezaki 2003). There was no significant difference in mean size among years (Fig. 2b), but we did find significant differences among months (ANOVA, $F_{11,300}=3.32$, p < 0.001). Turtles recorded in summer months (June through August) were significantly larger than those recorded in spring (March through May, see Fig. 4a). Based on the apparent separation of stocks proposed by Carreras et al. (2006), we tested for geographic differences in loggerhead turtle size. We found no difference between those turtles north $(54.2 \pm 12.4 \mathrm{~cm}, \mathrm{n}=$ $183)$ and south $(52.1 \pm 12.9 \mathrm{~cm}, \mathrm{n}=129)$ of Cape La Nao ( $t$-test: $t=1.75, \mathrm{p}=0.08)$.

\section{Seasonality}

Stranding records show a clear seasonal pattern, with records increasing in summer (July to August) (ANOVA, $F_{11,146}=8.534, \mathrm{p}<0.001$; Tukey post hoc comparison, $\mathrm{p}<0.01$, see Fig. $4 \mathrm{~b}$ ). Although subject to annual variation (Fig. 2c), neither the mean (Spearman's rank correlation, $r_{S}=-0.31, p=0.29$ ) nor the median day of strandings per year $\left(\mathrm{r}_{\mathrm{S}}=-0.51, \mathrm{p}=\right.$ 0.052) changed over time.

\section{Causes of stranding and mortality}

We investigated the likely cause of stranding of 393 turtles $(63.5 \%$ of the total) and found that $312(50.4 \%$ of the total) had stranded as a result of anthropogenic interaction. Of these, interactions with longline fishery were the most frequent $(12.2 \pm 11.5)$, accounting for 

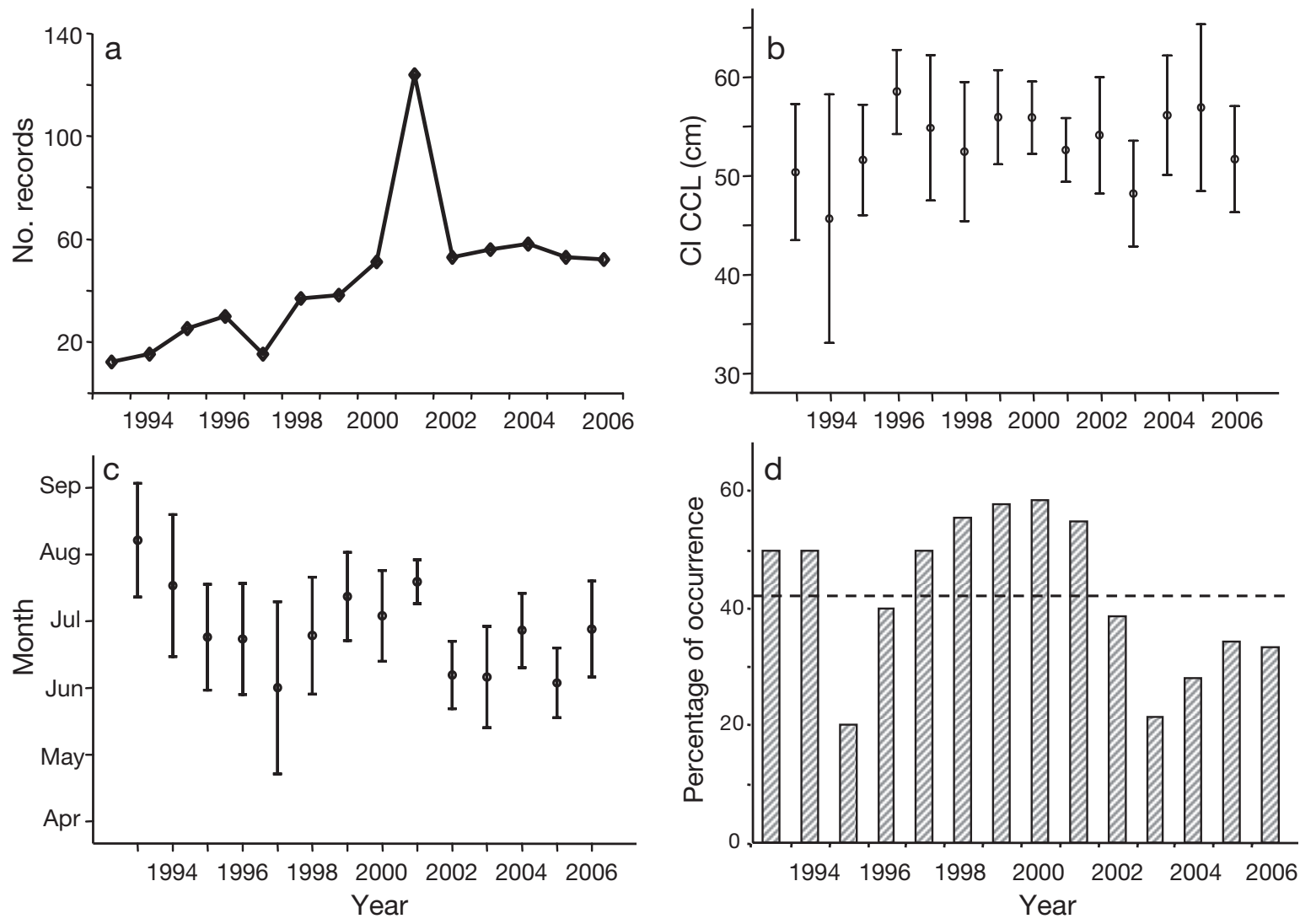

Fig. 2. Caretta caretta. Annual variation in (a) number of stranding records, (b) mean $\pm 95 \%$ CI of curved carapace length (CCL), (c) mean $\pm 95 \%$ CI monthly distribution of records, and (d) proportion of records assessed as resulting from longline interaction. Dashed line in (d) represents the annual mean percentage of occurrence of longline interaction

$27.6 \%$ of the total records $(43.5 \%$ of the records with an identified cause of stranding). However, in each of the most recent 5 yr the proportion of turtle strandings with an identified cause attributed to longline interactions was below the $14 \mathrm{yr}$ average $(42.6 \% \pm$ 13.2, Fig. 2d).

No significant difference was found in the relative proportion of strandings attributed to longline interaction between the northerly $(\mathrm{n}=84)$ and southerly $(\mathrm{n}=$ 85 ) areas off Cape La Nao $\left(\chi^{2}=0.006, \mathrm{df}=1, \mathrm{p}>0.05\right)$. Of the 171 turtles stranded due to longline interaction, 49 were rehabilitated in rescue centres and released back to the sea after tagging.

Carapace length of stranded turtles attributed to longline fisheries interactions was between 29.8 and $80.2 \mathrm{~cm}$ (mean CCL $=57.5 \pm 10.4 \mathrm{~cm}, \mathrm{n}=116$ ), but $90 \%$ of these turtles were between 40 and $74 \mathrm{~cm}$ (Fig. 3). Stranded turtles with signs of longline interaction were significantly larger than those without clear signs of longline interaction (mean CCL $=51.4 \pm 13.3 \mathrm{~cm}, \mathrm{n}=$ 196; $t=-4.49, \mathrm{p}<0.001)$. Most of the turtles with signs of longline interaction were stranded in summer months (June to September, Fig. 4c).

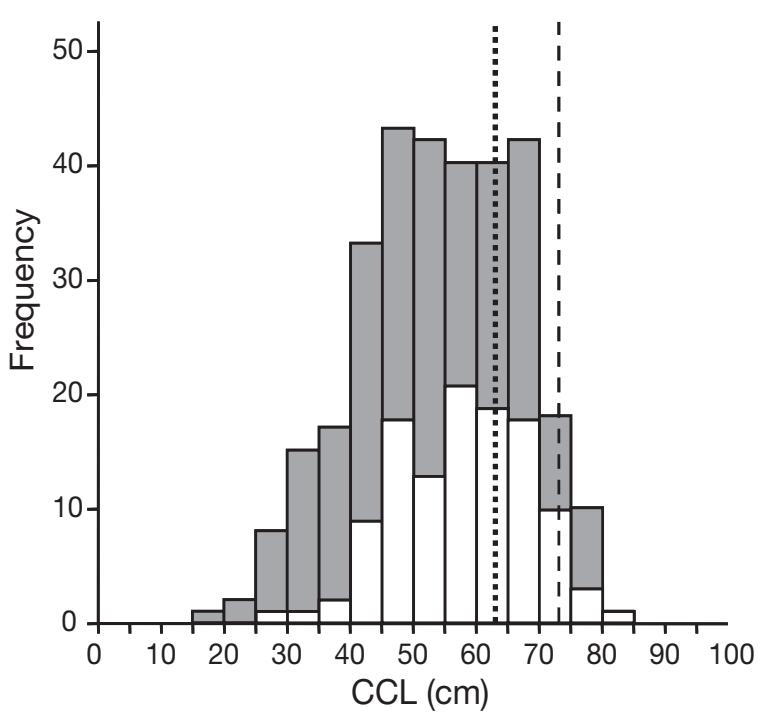

Fig. 3. Caretta caretta. Curved carapace length (CCL) of all measured turtles (grey bars, $\mathrm{n}=327$ ) and turtles interacting with longline fishery (white bars, $\mathrm{n}=116$ ) for 1993-2006. Dotted line: minimum carapace length for Mediterranean stocks (Broderick et al. 2003); dashed line: minimum carapace length for Atlantic stocks (Kamezaki 2003) 

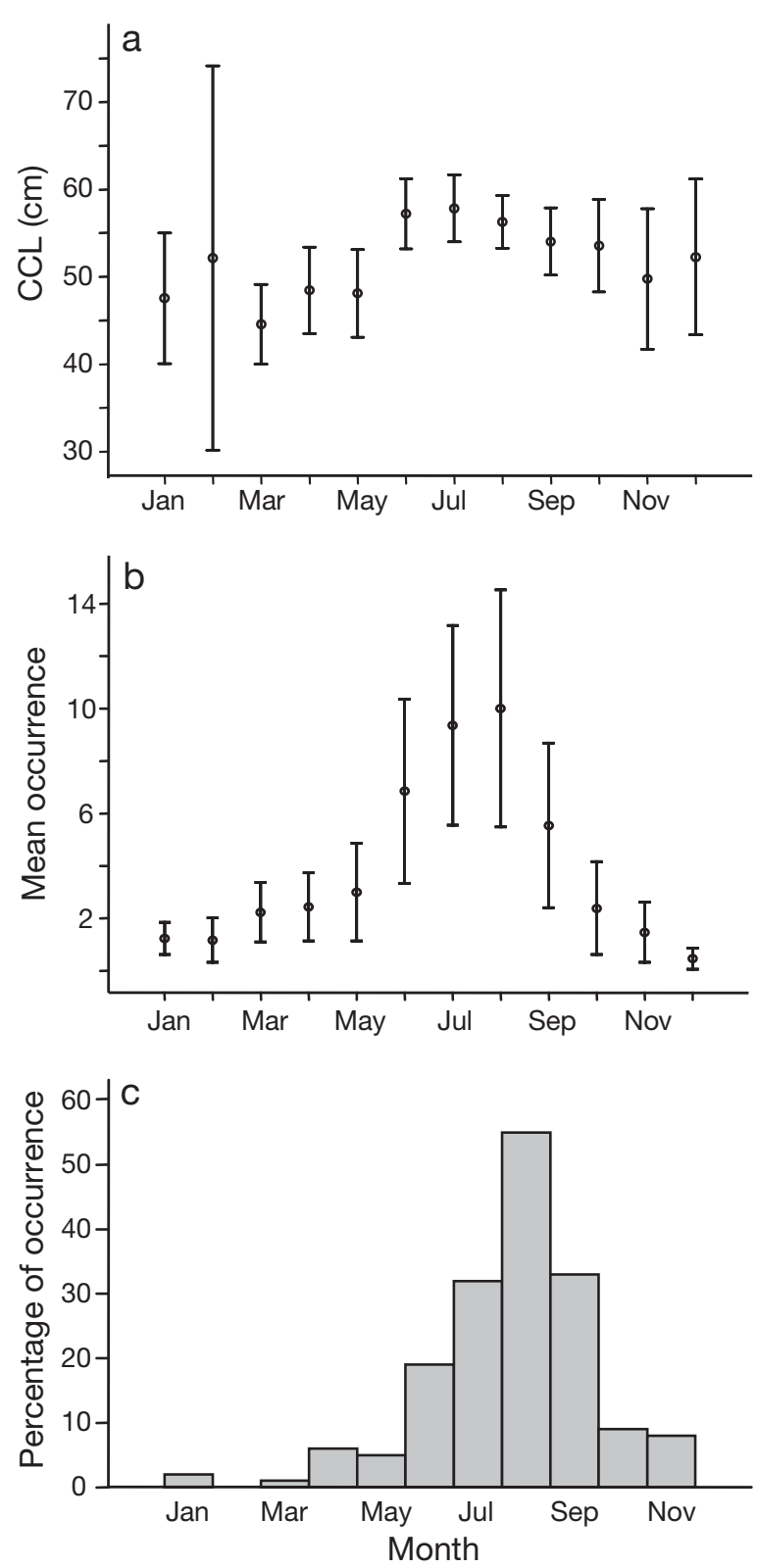

Fig. 4. Caretta caretta. Monthly variation in turtle records. (a) monthly mean $\pm 95 \%$ CI curved carapace length (CCL) of loggerhead turtles, (b) mean $\pm 95 \%$ CI proportion of annual occurrence of strandings in each month, (c) proportion of each monthly total assessed as having interacted with longline fisheries

Each of the anthropogenic causes of strandings other than longline fishing constituted less than $10 \%$ of the records. However, combined they accounted for a total of 145 strandings ( $23.9 \%$ of all records). Other fisheries that were recorded interacting with sea turtles accounted for $5.3 \%$ of records with known stranding cause.

In addition, $9 \%$ of stranded turtles in 2006 presented evidence of boat strikes.

\section{DISCUSSION}

Interaction with fisheries is a matter of concern for sea turtle conservation in the Mediterranean. Lewison et al. (2004a) suggest that the Mediterranean is a global hotspot for longline fishery interaction with loggerhead turtles. These authors estimated that 60000 to 80000 loggerhead turtles were captured by pelagic longline fisheries in the Mediterranean Sea in 2000. However, their analysis is based on homogeneous bycatch rates across the region, which may not be the case (Camiñas et al. 2006, Báez et al. 2007). Estimates of turtles captured yearly by the Spanish longline fishery, the largest of several fishing fleets in the western Mediterranean range, put loggerhead bycatch at between 2000 and 20000 individuals (Laurent et al. 2001, Mejuto et al. 2006 and references therein).

Our analyses suggest that, at minimum, half of the total number of turtle strandings over the period of our study were caused by interactions with human activities at sea, mainly fisheries. This number is consistent with other reports elsewhere in the Mediterranean (Casale et al. 2007). Elsewhere in Spain, 48\% of 147 stranded loggerhead turtles found alive along the coast of Andalusia in 2000 showed clear signs of interaction with fishing gear, $73 \%$ of these were demonstrated to have interacted with longline fisheries (Aula del Mar 2000).

For the Pacific Ocean, Lewison et al. (2004b) estimated that adult turtles have an approximately $50 \%$ chance of being hooked or entangled in longline fishing gear once each year. When a turtle is hooked by longline gear, depending on where the hook is embedded, they can face substantial risks. Most often, hooked turtles are not hauled aboard as fishermen often cut the line as soon as they are able to identify the species captured. If the hook and line are ingested, they may produce intussusception and other gut pathologies that can be lethal (Oros et al. 2005). However, data on post-hooking mortality, the likelihood that a turtle hooked by longline gear will die after it is released, are sparse. Although pre-release mortality in the western Mediterranean has been found to be very low, and most of the turtles are captured alive (Carreras et al. 2004, Camiñas et al. 2006), there have been few assessments of post-release mortality (Chaloupka et al. 2004). For turtles captured by longline fisheries in the Mediterranean, Casale et al. (2007) propose postrelease mortality $\geq 30 \%$, underlining the potentially important impact that longline bycatch may have on marine turtle stocks regionally.

The analysis of size class distribution of stranded loggerhead turtles demonstrates several interesting features. First, we observed that longline bycatch appears to be more prevalent in large juvenile and adult-sized 
turtles - age classes which may have a higher reproductive value and are therefore of great importance for the conservation of the species (Crowder et al. 1995, Lewison \& Crowder 2007). Similar size range has been reported in longline bycatch studies in the northeast Spanish Mediterranean (Pont \& Alegre 2000, Camiñas \& Valeiras 2001) and in other parts of the Mediterranean (Deflorio et al. 2005). This suggests that large juvenile loggerheads in the western Mediterranean exploit pelagic habitats (Laurent et al. 1998, Revelles et al. 2007a) and may not adhere strictly to the typical ontogenic pattern of habitat use proposed for the species (Bolten 2003). This is supported by the importance of pelagic feeding in large juvenile loggerhead revealed in dietary studies in the western Mediterranean (Tomás et al. 2001, Revelles et al. 2007b). Moreover, satellite tracking studies of this species have now also highlighted pelagic habitat use by large juveniles (Revelles et al. 2007a, McClellan \& Read 2007) and adults (Hatase et al. 2002, Hawkes et al. 2006), indicating an ever-more complicated picture of multiple lifehistory strategies (Witzell 2002, Godley et al. 2008).

Longline fisheries extend throughout the Spanish Mediterranean and surrounding waters (Báez et al. 2006, Mejuto et al. 2006, Camiñas et al. 2006). However, we recorded fewer strandings in the northern province (Castellón). This could be explained by the surface currents pattern proposed by Millot (1999; see our Fig. 1) and strandings distribution may be driven by the dominant north-south current along the Spanish coast. The perpendicular orientation of Cape La Nao to the main surface current would facilitate the concentration of strandings at the northern aspect of this cape. The southern part of the study area is west of a very important fishing zone known as 'El Patíbulo' (located approximately between $38^{\circ} 00^{\prime} \mathrm{N}, 00^{\circ} 30^{\prime} \mathrm{E}$ and $38^{\circ} 30^{\prime} \mathrm{N}, 01^{\circ} 00^{\prime} \mathrm{E}$ ), which is subject to high fishing effort not only by longliners, but also by trawlers and other gears. This concentration of fishing activity may be responsible for the level of human-related strandings in Alicante province.

In the Spanish Mediterranean, swordfish longline fisheries operate from spring to autumn, but concentrate effort in summer months (June to September; Pont \& Alegre 2000, De la Serna et al. 2004, Camiñas et al. 2006). Based on the seasonality of fishing effort, it is not surprising that stranding of turtles, particularly of turtles showing signs of longline interaction, mirrors this seasonality. De la Serna et al. (2004) reported a slight increase of fishing effort and a slight decrease of total captures of target species for the period 1998 to 2001 in the Spanish longline fishing fleet. A modification of the longline fishing gear introduced in 2003 in the fleet resulted in a considerable reduction of mean number of hooks per vessel (Báez et al. 2006, Camiñas et al. 2006). A considerable reduction in total captures of swordfish and tuna (both species targeted by longline) in the water surrounding the study area in 2004 and 2005 are reported compared to the period 1994 to 2003 (Generalitat Valenciana 2005). This is consistent with the general down-sizing of the whole Spanish fishing fleet and the reduction of captures of almost all fish species in the recent years, both in the studied region (Generalitat Valenciana 2005) and in the rest of Spain (MAPA 2007). This information would possibly explain the reduction of the impact of this fishery on loggerhead turtles in recent years. However, it is as yet too early to establish long-term trends in the fishery and its impact on sea turtles in the area. The possibility exists that some high seas fisheries will decline, perhaps due to overexploitation, before effective bycatch mitigation can be enacted.

\section{Other fisheries}

Other types of fishing gear, such as trawlers, static nets or trammel nets, are responsible for bycatch of non-targeted marine vertebrates in the Mediterranean (Carreras et al. 2004, Casale et al. 2005, Karamanlidis et al. 2008, this Theme Section [TS]), and further afield (Epperly et al. 2007, Slooten 2007, Chilvers 2008, this TS). Compared to longlines, relatively little research effort has been directed at assessing the impact of other such gear on sea turtles (Godley et al. 1998, Casale et al. 2005). Interaction with other fisheries has been highlighted in areas near the studied region (Bertolero 2003, Carreras et al. 2004). It is possible that the impact of other kinds of fishing methods, such as trawling, will be underestimated in the studied area, since assessment studies are scarce and the available information comes only from vessel logbooks and occasional reports at a regional level.

\section{Insights into natural history}

Most stranded individuals were within the ranges of typical juvenile sizes reported for the Mediterranean (Margaritoulis et al. 2003) and the Atlantic populations (Bolten 2003). However, adults may also be present in our sample; in the Mediterranean, nesting females of less than $65 \mathrm{~cm}$ CCL have been reported (Broderick et al. 2003, Margaritoulis et al. 2003 and references therein). Similar size distributions have been found in strandings in Catalonia, north of our study area (Pont \& Alegre 2000, Bertolero 2003). Although genetic studies suggest that turtles either side of Cape La Nao are from different stocks (Carreras et al. 2006), we did not find a difference in size of turtles north and south of 
Cape La Nao. This supports the findings of Carreras et al. (2006), that there were no size differences between turtles with Atlantic and Mediterranean haplotypes in the Spanish Mediterranean.

North of Cape La Nao, we report a decrease in number of strandings with increasing latitude. However, at-sea studies have reported a high density of turtles in the waters surrounding the northern part of the study area throughout the year (Gómez de Segura et al. 2003, 2006). Furthermore, no differences in density were found north and south of Cape La Nao in aerial surveys performed between 2001 and 2003 (Gómez de Segura et al. 2006). Thus, abundance and distribution of strandings are more likely linked to interaction with fisheries and the predominant current patterns than to the abundance and distribution of regional stocks. However, in some cases stranding data can help in the detection of dramatic variations in the composition of regional stocks of marine vertebrates and changes in their seasonal distribution patterns (e.g. Aguilar 2000). For instance, the substantial increase in strandings in June 2001 was likely related to a massive influx of turtles into the study area (Tomás et al. 2003a).

The present study provides data on turtle strandings throughout the year, but the majority of these strandings occur in the spring, summer and early autumn (between April and October). This is consistent with other studies on the Spanish Mediterranean coast (e.g. Bertolero 2003). However, aerial surveys have shown no differences in density between seasons (with the exception of spring 2001, Gómez de Segura et al. 2006). Here, the seasonality in strandings is most likely explained by the increase of fishing activity in summer months (Carreras et al. 2004, Camiñas et al. 2006). The fact that no significant seasonality has been detected in cetacean stranding pattern, also recorded by the same network in the same region (University of Valencia Marine Zoology Unit unpubl. data), supports this explanation. Cetaceans exhibit substantially lower levels of longline fishery interactions than turtles.

\section{CONCLUSIONS}

Compared to studies at nesting beaches, studies of sea turtles at sea are subject to many methodological and economic constraints. Data from stranding networks can be biased due to seasonal and spatial variation in recording, and interannual variation in surveying (see Hart et al. 2006 and Witt et al. 2007). Despite these limitations, long-term stranding studies can give insight into sea turtle biology, population dynamics and, particularly, threats at sea. However, in order to provide accurate information, stranding networks must employ repeatable protocols and constant search effort over designated areas. Although the numbers of records in the earlier years of our study period were likely influenced by changes in detection and search effort, our data set provides valuable information on anthropogenic mortality sources in this region.

Fisheries and other disturbances in the study region affect turtles from different population stocks: the Atlantic and the Mediterranean (Laurent et al. 1998, Carreras et al. 2006 and references therein). Because the Mediterranean stock is far smaller than the Atlantic stock (see Broderick et al. 2002, Margaritoulis et al. 2003), a more detailed assessment of turtle-fishery interaction in the Mediterranean that is able to identify stock source of affected individuals is essential.

Interactions with longlines were found to be the main cause of observed turtle mortality. However, we also found evidence that the potential impact of longlining on western Mediterranean loggerhead turtles may have decreased in recent years. Future integrated studies, including at-sea surveys of sea turtle abundance, fisheries effort through direct or indirect methods (Witt \& Godley 2007), together with stranding records collected by an effective and standardized network, will help to offer insight into the biology of sea turtles and the role of different anthropogenic threats on this species in the area.

Acknowledgements. This study was supported by the Conselleria de Medio Ambiente, Agua, Urbanismo y Vivienda of the Generalitat Valenciana. Thanks are also given to the staff of the Marine Zoology Unit of the Cavanilles Research Institute of Biodiversity and Evolutionary Biology (University of Valencia) for their valuable help. We thank L. Hawkes, M. Witt, C. Bell and R. Leeney for constructive criticism of early drafts. We are also grateful for the useful critiques offered by Dr. Lewison and 3 anonymous reviewers that greatly improved the manuscript. J.T. is supported by a Marie Curie Postdoctoral Fellowship, and B.J.G. receives support from European Social Fund Project number 041015SW1 and the Natural Environment Research Council.

\section{LITERATURE CITED}

Aguilar A (2000) Population biology, conservation threats and status of Mediterranean striped dolphins (Stenella coeruleoalba). J Cetacean Res Manag 2:17-26

Aula del Mar (2000) Informe de tortugas marinas liberadas en 2000. Resumen de actuaciones CREMA. Available at: http://www. auladelmar.info/crema/estadisticas.htm

Báez JC, Camiñas JA, Rueda L (2006) Accidental fishing capture of marine turtles in South Spain. Mar Turtle Newsl 111:11-12

Báez JC, Real R, Camiñas JA (2007) Differential distribution within longline transects of loggerhead turtles and swordfish captured by the Spanish Mediterranean surface longline fishery. J Mar Biol Assoc UK 87:801-803

Bertolero A (2003) Varamientos y capturas de tortugas marinas en los alrededores del Delta del Ebro (NE España) entre los años 1984 y 2001. Rev Esp Herpetol 17:39-54 
Bolten AB (2003) Active swimmers - passive drifters: The oceanic juvenile stage of loggerhead in the Atlantic system. In: Bolten AB, Witherington BE (eds) Loggerhead sea turtles. Smithsonian Institution Press, Washington, DC, p 63-78

Broderick AC, Glen F, Godley BJ, Hays GC (2002) Estimating the number of green and loggerhead turtles nesting annually in the Mediterranean. Oryx 36:227-236

Broderick AC, Glen F, Godley BJ, Hays GC (2003) Variation in reproductive output of marine turtles. J Exp Mar Biol Ecol 288:95-109

Broderick AC, Coyne MS, Fuller WJ, Glen F, Godley BJ (2007) Fidelity and overwintering of sea turtles. Proc R Soc Lond B Biol Sci 274:1533-1538

Camiñas JA, De la Serna JM (1995) The loggerhead distribution in the western Mediterranean Sea as deduced from captures by the Spanish long-line fishery. In: Llorente GA, Montori A, Santos X, Carretero MA (eds) Scientia Herpetologica, Barcelona, p 316-323

Camiñas JA, Valeiras J (2001) Marine turtles, mammals and sea birds captured incidentally by the Spanish surface longline fisheries in the Mediterranean Sea. Rapp P-V Reun Comm Int Explor Sci Mer Mediterr 36:248

Camiñas JA, Báez JC, Valeiras X, Real R (2006) Differential loggerhead bycatch and direct mortality due to surface longlines according to boat strata and gear type. Sci Mar 70:661-665

Cardona L, Revelles M, Carreras C, San Félix M, Gazo M, Aguilar A (2005) Western Mediterranean immature loggerhead turtles: habitat use in spring and summer assessed through satellite tracking and aerial surveys. Mar Biol 147:583-591

Carranza A, Domingo A, Estrades A (2006) Pelagic longlines: A threat to sea turtles in the Equatorial Eastern Atlantic. Biol Conserv 131:52-57

Carreras C, Cardona L, Aguilar A (2004) Incidental catch of the loggerhead turtle Caretta caretta off the Balearic Islands (western Mediterranean). Biol Conserv 117: 321-329

Carreras C, Pont S, Maffucci F, Pascual M and others (2006) Genetic structuring of immature loggerhead sea turtles (Caretta caretta) in the Mediterranean Sea reflects water circulation patterns. Mar Biol 149:1269-1279

Casale P, Freggi D, Basso R, Argano R (2005) Interaction of the static net fishery with loggerhead sea turtles in the Mediterranean: insights from mark-recapture data. Herpetol J 15:201-203

Casale P, Freggi D, Rocco M (2007) Mortality induced by drifting longline hooks and branchlines in loggerhead sea turtles, estimated through observation in captivity. Aquat Conserv 18(6):945-954

Chaloupka M, Parker D, Balazs G (2004) Modelling postrelease mortality of loggerhead sea turtles exposed to the Hawaii-based pelagic longline fishery. Mar Ecol Prog Ser 280:285-293

Chilvers BL (2008) New Zealand sea lions Phocarctos hookeri and squid trawl fisheries: bycatch problems and management options. Endang Species Res 5:193-204

Crowder LB, Hopkins-Murphy SR, Royle A (1995) Effects of turtle excluder devices (TEDs) on loggerhead sea turtle strandings with implications for conservation. Copeia 1995:773-779

De la Serna JM, Macias D, Ortiz de Urbina JM, Alot E, Rioja P (2004) Análisis de la pesquería española del pez espada (Xiphias gladius) en el Mediterráneo. Collect Vol Sci Pap ICCAT 56(3): 864-871 www.iccat.int/Documents/CVSP/ CV056_2004/no_3/CV056030864.pdf
Deflorio M, Aprea A, Corriero A, Santamaría N, De Metrio G (2005) Incidental captures of sea turtles by swordfish and albacore longlines in the Ionian sea. Fish Sci 71: 1010-1018

Epperly SP, Braun-McNeill J, Richards PM (2007) Trends in catch rates of sea turtles in North Carolina, USA. Endang Species Res 3:283-293

Generalitat Valenciana (2005) Pesca marítima desembarcada en los puertos de la C. valencia. In: Informe del sector agrario 2005, XIV Pesca Marítima. Generalitat Valenciana. Available at: www.agricultura.gva.es/ coyuntura/cast/publicaciones/ISAV/ISAV-2005/Documents/ Cap14-03.pdf

Gerosa G, Casale P (1999) Interaction of marine turtles with fisheries in the Mediterranean. Regional Activity Centre for Specially Protected Areas, Mediterranean Action Plan, UNEP, Tunis. Available at: http://iodeweb1.vliz.be/ odin/bitstream/1834/750/1/INTERACTION_eng.pdf

Godley BJ, Gücü AC, Broderick AC (1998) Interaction between marine turtles and artisanal fisheries in the eastern Mediterranean: a probable cause for concern? Zool Middle East 16:49-84

> Godley BJ, Broderick AC, Glen F, Hays GC (2003) Post-nesting movements and submergence patterns of loggerhead marine turtles in the Mediterranean assessed by satellite tracking. J Exp Mar Biol Ecol 287:119-134

> Godley BJ, Blumenthal JM, Broderick AC, Coyne MS, Godfrey $\mathrm{MH}$, Hawkes LA, Witt MJ (2008) Satellite tracking of sea turtles: Where have we been and where do we go next? Endang Species Res 4:3-22

> Gómez de Segura A, Tomás J, Pedraza SN, Crespo EA, Raga JA (2003) Preliminary patterns of distribution and abundance of loggerhead sea turtles, Caretta caretta, around Columbretes Island marine Reserve, Spanish Mediterranean. Mar Biol 143:817-823

Gómez de Segura A, Tomás J, Pedraza SN, Crespo EA, Raga JA (2006) Abundance and distribution of the endangered loggerhead turtle in Spanish Mediterranean waters and its conservational implications. Anim Conserv 9:199-206

Hall MA, Alverson DL, Metuzals KI (2000) By-catch: problems and solutions. Mar Pollut Bull 41(1-6): 204-219

Hart KM, Mooriside P, Crowder LB (2006) Interpreting the spatio-temporal patterns of sea turtle strandings: going with the flow. Biol Conserv 129:283-290

> Hatase H, Takai N, Matsuzawa Y, Sakamoto W and others (2002) Size-related differences in feeding habitat use of adult female loggerhead turtles Caretta caretta around Japan determined by stable isotope analyses and satellite telemetry. Mar Ecol Prog Ser 233:273-281

> Hawkes LA, Broderick AC, Coyne MS, Godfrey MS and others (2006) Phenotypically linked dichotomy in sea turtle foraging requires multiple conservation approaches. Curr Biol 16:990-995

Hays GC, Broderick AC, Godley BJ, Luschi P, Nichols WJ (2003) Satellite telemetry suggests high levels of fishinginduced mortality in marine turtles. Mar Ecol Prog Ser 262:305-309

Kamezaki N (2003) What is a loggerhead turtle? The morphological perspective. In: Bolten AB, Witherington BE (eds) Loggerhead sea turtles. Smithsonian Institution Press, Washington, DC, p 28-43

Karamanlidis AA, Androukaki E, Adamantopoulou S, Chatzispyrou A and others (2008) Assessing accidental entanglement as a threat to the Mediterranean monk seal Monachus monachus. Endang Species Res 5:205-213

Kemf E, Groombridge B, Abreu A, Wilson A (2000) Marine turtles in the wild. A World Wide Fund for Nature species 
status report, Gland. Available at: www.wwf.or.jp/ activity/ wildlife/lib/marineturtles/wwfturt.pdf

Laurent L, Casale P, Bradai MN, Godley BJ and others (1998) Molecular resolution of marine turtle stock composition in fishery bycatch: a case study in the Mediterranean. Mol Ecol 7:1529-1542

Laurent L, Camiñas JA, Casale P, Deflorio $\mathrm{M}$ and others (2001) Assessing marine turtle bycatch in European drifting longline and trawl fisheries for identifying fishing regulations. Final report on project-EC-DG Fisheries 98-008. Joint project of BIOINSIGHT, IEO, IMBC, STPS and University of Bari, Villeurbanne

Lewison RL, Crowder LB (2007) Putting longline bycatch of sea turtles into perspective. Conserv Biol 21:79-86

Lewison RL, Freeman SA, Crowder LB (2004a) Quantifying the effects of fisheries on threatened species: the impact of pelagic longlines on loggerhead and leatherback sea turtles. Ecol Lett 7:221-231

Lewison RL, Crowder LB, Read AJ, Freeman SA (2004b) Understanding impacts of fisheries bycatch on marine megafauna. Trends Ecol Evol 19:598-604

MAPA (2007) Hechos y cifras de la agricultura, la pesca, y la alimentación en España. Ministerio de Agricultura, Pesca y Alimentación 2007. Available at: www.mapa.es/ministerio/pags/hechoscifras/espanol/pdf/24.pdf

Margaritoulis D, Argano R, Baran I, Bentivegna F and others (2003) Loggerhead turtles in the Mediterranean sea: present knowledge and conservation perspectives. In: Bolten $A B$, Witherington BE (eds) Loggerhead sea turtles. Smithsonian Institution Press, Washington, DC, p 175-198

McClellan CM, Read AJ (2007) Complexity and variation in loggerhead sea turtle life history. Biol Lett 3:592-594

Mejuto J, De la Serna JM, Valeiras J, Camiñas JA and others (2006) Actuaciones en el marco de proyectos de investigación relacionadas con el estudio de las interacciones entre las pesquerías de túnidos y especies afines y las tortugas marinas. Instituto Español de Oceanografía. Available at: www.mapa.es/pesca/pags/sostenibilidad_p/ tortugaypesca/proyecto_ieo.pdf

Millot C (1999) Circulation in the western Mediterranean Sea. J Mar Syst 20:423-442

Orós J, Torrent A, Calabuig P, Déniz S (2005) Diseases and causes of mortality among sea turtles stranded in the Canary Islands, Spain (1998-2001). Dis Aquat Org 63: 13-24

Panagopoulos D, Sofouli E, Teneketzis K, Margaritoulis D (2003) Stranding data as an indicator of fisheries induced mortality of sea turtles in Greece. In: Margaritoulis D, Demetropoulos A (eds) Proc 1st Mediterr Conf Mar Turtles. Barcelona-Bern-Bonn Convention (CMS), Nicosia, p 202-206

Peckham SH, Diaz DM, Walli A, Ruiz G, Crowder LB, Nichols WJ (2007) Small-scale fisheries bycatch jeopardizes endangered pacific loggerhead turtles. PLoS One 2:e1041

Editorial responsibility: Rebecca Lewison, San Diego, California, USA
Pont S, Alegre F (2000) Work of the Foundation for the Conservation and Recovery of Marine Life. Mar Turtle Newsl 87:5-7

Raga JA, Salinas J (1990) Sur la présence de la tortue verte Chelonia mydas (Linnaeus, 1758), en Mediterranée Occidentale. P-V Reun Comm Int Explor Sci Mer Mediterr 23(1): 241

Revelles M, Cardona L, Aguilar A, San Félix M, Fernández G (2007a) Habitat use by immature loggerhead sea turtles in the Algerian Basin (western Mediterranean): swimming behaviour, seasonality and dispersal pattern. Mar Biol 151:1501-1515

Revelles M, Cardona L, Aguilar A, Borrell A, Fernández G, San Félix M (2007b) Stable C and N isotope concentration in several tissues of the loggerhead sea turtle Caretta caretta from the western Mediterranean and dietary implications. Sci Mar 71:87-93

Sasso CR, Epperly SP (2007) Survival of pelagic juvenile loggerhead turtles in the open ocean. J Wildl Manag 71: 1830-1835

> Slooten E (2007) Conservation management in the face of uncertainty: effectiveness of four options for managing Hector's dolphin bycatch. Endang Species Res 3:169-179

Snover ML, Avens L, Hohn AA (2007) Back-calculating length from skeletal growth marks in loggerhead sea turtles Caretta caretta. Endang Species Res 3:95-104

Tomás J, Raga JA (2007) Occurrence of Kemp's ridley sea turtle (Lepidochelys kempii) in the Mediterranean. J Mar Biol Assoc UK, Biodiversity Records. Available at: www.mba. ac.uk/jmba/pdf/5640.pdf

Tomás J, Aznar FJ, Raga JA (2001) Feeding ecology of the loggerhead turtle Caretta caretta in the western Mediterranean. J Zool 255:525-532

Tomás J, Fernández M, Raga JA (2003a) Sea turtles in Spanish Mediterranean waters: surprises in 2001. Mar Turtle Newsl 101:1-3

Tomás J, Formia A, Fernández M, Raga JA (2003b) Occurrence and genetic analysis of a Kemp's ridley sea turtle (Lepidochelys kempii) in the Mediterranean Sea. Sci Mar 67:367-369

Witt MJ, Godley BJ (2007) A step towards seascape scale conservation: using Vessel Monitoring Systems (VMS) to map fishing activity. PLoS One 2:e1111

Witt MJ, Penrose R, Godley BJ (2007) Spatio-temporal patterns of juvenile marine turtle occurrence in waters of the European continental shelf. Mar Biol 151:873-885

Witzell WN (2002) Immature Atlantic loggerhead turtles (Caretta caretta): suggested changes to the life history model. Herpetol Rev 33:266-269

> Zbinden JA, Aebischer A, Margaritoulis D, Arlettaz R (2008) Important areas at sea for adult loggerhead sea turtles in the Mediterranean Sea: satellite tracking corroborates findings from potentially biased sources. Mar Biol 153:899-906

Submitted: November 15, 2007; Accepted: June 15, 2008 Proofs received from author(s): September 14, 2008 